\title{
INFLUENCE OF LOCUS OF CONTROL ON JOB STRESS OF TEACHERS IN JAFFNA
}

\author{
* Thaneswary Raveendran \\ Department of Human Resource Management, University of Jaffna \\ rthanes@univ.jfn.ac.lk
}

Anusha Sivaneswaran

Faculty of Arts, University of Jaffna

drarts@univ.jfn.ac.lk

\begin{abstract}
The present study sought to investigate the relationship between locus of control and stress among school teachers. Teaching job is regarded as one of the most stressful occupation, but so far, no study explored the association between locus of control and stress of school teachers in Jaffna. Although previous research results have indicated that there is an association between personality and behavioral outcomes, there has been little attention paid to some of the personality factors that may impact these relationships. The purpose of this study is to examine the job stress, internal and external locus tendencies and the relationship between the two construct. Subjects were drawn from randomly selected schools from Jaffna Zone. 186teachers participated in this study. Locus of control was measured using Locus of Control Scale and stress level was measured using Perceived Stress Scale. The result indicates that individuals with a higher external locus of control are more likely to have higher levels of job stress.
\end{abstract}

Keywords: Locus of Control; Externals; Internals; Job Stress 


\section{Introduction}

Locus of Control refers to ones beliefs that outcomes are determined by either oneself, luck or significant others. There are two types of locus of control, the internal locus of control and External locus of control. Internal locus of control refers to people who believe in themselves and their abilities. In this study, they teachers who believe that whatever happens to them is due to their own efforts and not from outside influence. On the other hand, external locus of control involves the belief of people that rewards or outcomes are determined by either luck or others with more power than them.

Job stress has long been an important concept in the study of employees' responses to their work surroundings. Job stress has been defined as the non-specific response of the body to any demands made upon it (Selye, 1976).In general, Job stress can be defined as the physical and emotional responses that happen when the employee's capabilities and resources cannot be coped with the demands and requirements of their job (Lindholm, 2006; Nakasis \&Ouzouni, 2008). Stress is a natural part of life, and occurs whenever there are significant changes in our lives, whether positive or negative. It is generally believed that some stress is okay (sometimes referred to as "challenge" or "positive" stress) but high stress is harmful. Thus, stress, while being essential to life, also seems to be a killer.

Although previous research results have indicated that an association between personality and behavioral outcomes exists, there has been little attention paid to some of the factors that may impact these relationships. For example, individuals in a teaching profession may respond differently than individuals in a job that is not associated with a specific profession. Studies have been reviewed on relationship between locus of control and stress. For example, Sunbull (2011) showed that external locus of control was positively and directly related to emotional exhaustion dimension of burnout. Howart (2012) surveyed teachers and found that a person with an internal locus of control believes that rewards in life are guided by their own decision and efforts. Sabrain, Omidiyar, Gharizadeh and Bazrafshan (2014) found that locus of control plays a significant role in stress management and increase or decrease negative emotions notably in the working environment. There are measures that individuals and organizations can take to alleviate the negative impact of stress. 
Workplace stress does not have the same effect on all individuals. There are a range of personal, social, and environmental moderators within each of us that influence our susceptibility and coping abilities in relation to the stressors we experience. One of the personality factors that have been found to affect individual reactions to stressors is known as the "locus of control". People can be differentiated on the basis of their 'generalized expectancy' concerning internal and external control of life events and outcomes.

\section{Objective of the Study}

The primary objective of this study was to assess how locus of control impacts teachers' job stress in Jaffna schools. In addition, little or no research has focused on the potential impact of locus of control in the workplace behaviour. Further, since the majority of research has focused on Western organizations, it was thought that an Asian perspective would add to the understanding of both the variables studied and possibly cultural differences.

\section{Research Question}

This study examined the influence of locus of control on individual's job-related stress. The research problem focused here was:

Does locus of control predict job stress of school teachers in Jaffnafi

\section{Literature Review}

In the present scenario there is the changing time in every field around the world. With the start of new millennium, societies are engaging in serious and promising educational reforms. One of the key factors in these reforms is the school teachers. Understanding teachers' perceptions and beliefs is important because teachers heavily involved in various teaching and learning processes, and they are practitioners of educational principles and theories

In psychology, Locus of Control is considered to be an important aspect of personality. The concept was developed originally by Rotter (1966).A locus of control orientation is a belief about whether the outcomes of our actions are contingent on what we do (internal control orientation) or on events outside our personal control (external control orientation).Thus, locus of control is 
conceptualized as referring to a unidimensional continuum, ranging from external to internal: Individual with External Locus of Control believes that his/her behaviors is guided by fate, luck, or other external circumstances. Individual with internal Locus of Control believes that his/her behaviors is guided by his/her personal decisions and efforts.

In simplistic terms, a more internal locus of control is generally seen as desirable. Having an Internal locus of control can also be referred to as "self-agency", "personal control", "self determination", etc. Research has found the following trends: males tend to be more internal than females; as people get older they tend to become more internal; people higher up in organizational structures tend to be more internal (Mamlin, Harris, \& Case, 2001). Internal locus of control people accept responsibility for events (Davis and Davis, 1972), and external locus of control individuals blame their environment for failures (Phares, Wilson \& Klyver, 1971). Because internal locus-of-control individuals ("internals") believe they control the events in their lives, they recognize that experiences are related. Given this, internals believe that the probability of goal attainment is directly proportional to their efforts and their ability to learn from repeated experiences (Lefcourt, 1982) and also set more difficult goals for themselves (Yukl \& Latham, 1978), which reflect their perception of control (Murray, 1990). Externals do not see the relationship between their efforts and the ultimate results of these efforts (Lefcourt, 1982).

Chan (1977) suggests that when individuals perceive that they are in control of a situation (internals) "the probability is that they will be less likely to perceive the situation as threatening or stress-inducing".Ivancevich and Matteson (1980) believe that the types of locus of control and adaptation to stress are related. Since internal-locus-of-control individuals experience lower anxiety (Torestad, Olah \& Magnusson 1989), internal locus of control may act as a stress buffer (Daniels \& Guppy, 1992). Externality (i.e., more fate, chance, luck, or powerful others oriented) is positively correlated with general life stress (DiMatteo, Shugars, \& Hays 1993) and job stress (Evans \& Coman, 1993).

In the study of locus of control and occupational stress of oil workers, Meng, $\mathrm{He}$, Yu and Qi (2008) showed that Work locus of control is associated with many occupational stress factors. They found that the group of extrinsic (external) work 
locus of control experience more stress in oil workers. Halpin, Harris and Halpin (1985) showed that locus of control was related to teacher stress. They found that teachers who felt that they were in control reported less stress in their world of work than did those who did not feel influential in their educational environment.

Lowe (2019) investigated the effects of adaptive coping styles and locus of control on stress outcome. Findings suggest that when internal locus of control is moderate or high, and individuals endorse high levels of perceived stress, they indicate that they are less productive at work due to health issues. Sünbül (2003) reported that external locus of control was positively and directly related to emotional exhaustion dimension of burnout. Jha and Bano (2012) found that employees who have internal locus of control are less stressed by their jobs and more satisfied with the organization while the external locus of control employees are high on stress and more dissatisfied with their jobs. A recent research reported that external locus of control positively impacts job stress(Sinha \& Sharma, 2019). In a nutshell organizations should aim to develop strategies to reinforce internal locus of control in the employees so as to ensure stress free and satisfied work force.

Although previous research results have indicated that there is an association between personality and behavioral outcomes, there has been little attention paid to some of the personality factors that may impact these relationships. The current study examines the relationship between internal and external locus tendencies and stress of teachers.

\section{Hypothesis}

Based on these prior findings the following hypothesis was formulated and tested:

Teachers with external locus of control would report more job stress than those with internal locus of control.

\section{Method}

\section{Sample}

In this study, selection of participants was based on a random sample from school teachers in Jaffna District. A total of 245 questionnaires were distributed and 186 were returned. The response rate is $76 \%$. 


\section{Measures}

Locus of control was measured using Work Locus of Control Scale (Spector, 1988). Locus of Control Scale is a 16 item questionnaire where respondents were asked to select the responses from a 6 point scale. Eight of the items measure external locus of control and eight items measure internal locus of control. Sample items were "A job is what you make of it", "Getting the job you want is mostly a matter of luck". Participant rated the extent of agreement from 1 (representing strongest disagreement) to 6 (representing strongest agreement) with each item. Spector (1988) suggests that high scores on the scale represent externality, so the scores on the internally worded (internal locus of control) items must be reversed before summing. This is because a score of 6 representing strongest possible agreement on an externally worded item is equivalent to a score of 1 representing strongest possible disagreement on an internally worded item.

Participants' stress levels were investigated using Cohen et al's (1983) Perceived Stress Scale (PSS). The PSS is a 10-item questionnaire which measures the degree to which respondents have felt stress in the past month. Sample item was 'In the last month how often have you felt that you were able to control the important things in your lifefi'. Participants rated the extent of agreement on a scale of 0 (never) to 4 (very often). The relevant items were reversed and the items were added up to give an overall score. Scores range from 0-40 and higher scores reflect greater perceived stress.

In order to test for reliability within the instruments, Cronbach's Alpha tests were conducted on each factor. The instruments used in this study were reliable with coefficients .723 and .846 for Locus of Control Scale and Perceived Stress Scale respectively.

\section{Results and Discussion}

The analyses were carried out using the Statistical Package for the Social Sciences (SPSS20.0).The results in Table 1 show that the mean score for the Locus of Control Scale was 37.31, and the standard deviation was 10.36. The mean score for Stress was 18.77and the standard deviation was 11.236. Correlation result shows that there is moderate positive relationship between locus of control and stress $(\mathrm{r}=0.433 \& \mathrm{p}<0.01)$. 
Table 1: Correlation and Mean values

\begin{tabular}{|l|l|l|l|l|}
\hline & 1 & 2 & Mean & Std. deviation \\
\hline 1.Locus of control & & $.433^{* *}$ & 4.66 & 1.29 \\
\hline 2. Stress & & & 1.88 & 0.62 \\
\hline & & & & \\
\hline
\end{tabular}

** Correlation is significant at the 0.01 level

Source : Survey Data

Table 2 a: Regression Model Summary

\begin{tabular}{|l|r|r|r|r|r|r|}
\hline Model & R & R Square & $\begin{array}{c}\text { Adjusted R } \\
\text { Square }\end{array}$ & $\begin{array}{c}\text { Std. Error of the } \\
\text { Estimate }\end{array}$ & F & Sig. \\
\hline 1 & .537 & .288 & .283 & 8.176 & 3.22 & .000 \\
\hline
\end{tabular}

Source : Survey Data

Table 2 b: Regression Coefficients

\begin{tabular}{|l|r|r|r|r|r|}
\hline \multirow{2}{*}{ Model } & \multicolumn{2}{|c|}{$\begin{array}{c}\text { Unstandardized } \\
\text { Coefficients }\end{array}$} & $\begin{array}{c}\text { Standardized } \\
\text { Coefficients }\end{array}$ & \multirow{2}{*}{ Sig. } & \\
\cline { 2 - 4 } & \multicolumn{1}{|c|}{$\mathrm{B}$} & Std. Error & \multicolumn{1}{c|}{ Beta } & & \\
\hline (Constant) & 41.69 & 5.101 & & 8.124 & .000 \\
\hline Internal Locus of control & -.142 & .028 & .218 & -1.013 & .021 \\
\hline External Locus of control & .466 & .192 & .329 & 2.112 & .047 \\
\hline . Dependent Variable: Stress
\end{tabular}

Source : Survey Data

In accordance with the Table 2-b,internal locus of control has a negative impact on job stress $(B=-0.142, p<0.05)$ whereas external locus of control has a positive impact on job stress $(B=0.466, p<0.05)$. The results indicate that there is significant relationship between locus of control and job stress. In this model, an R2 value of . 288 denotes that $28.8 \%$ of the observed variability in job stress can be explained by locus of control.

As per the results of regression, the impact of external locus of control on job stress is positive $(\mathrm{B}=0.466)$ while the impact of internal locus of control on job stress is negative $(B=-0.142)$.Therefore, it can be proved that 'Externals' have high job stress. From the finding, the hypothesis: 'Teachers with external Locus of control would report more job stress than those with internal Locus of control is supported. The results of the present study is consistent with the previous studies (for 
example, Daniels \& Guppy, 1992; Evans \& Coman, 1993; Meng, He, Yu\&Qi,2008; Sinha \& Sharma, 2019). Internal locus of control individuals tend to be more adaptive in dealing with task-related problems, along with the results of these findings the authors believed that teachers with internal locus of control can better cope with stress than those with external locus of control. The reason behind the Internal's ability to cope well with stressful situations is that they believe their own abilities and efforts control the things that happen to them, are independent, like to participate in decisions, are involved in work, adjust to work and handle job stress well, like to influence others, are future oriented rather than present oriented, are achievement oriented, and may chafe under too many rules, restrictions, and rigidity. Externals believe that others, situations, and fate control what happens to them. They prefer structure, do not like to work independently, have few expectations based on past successes or failures, and are susceptible to influence attempts by others.

\section{Conclusion and Implications}

The results of this study show that external locus of control has a significant positive effect on work stress. Locus of control as a personality trait that influences individual stress levels, determines how individuals react to stressful or stressful situations. Locus of control refers to a measure that shows how individuals perceive the possibility of a relationship between the actions carried out and the results obtained. Some psychological and educational interventions have been found to produce shifts towards internal locus of control (Hans, 2000). There are several potential implications of these results for school teachers in Jaffna and possibly elsewhere. Since locus of control was an important antecedent of teachers' work-related stress, school principals need to consider this aspect in getting work done.

Future research could include personality variables other than locus of control and for different professions. In addition, the replication of this study in places other than Jaffna would help generalizability of these findings. 


\section{References:}

Chan, K. B. (1977). Individual differences in reactions to stress and their personality and situational determinants. Social Science and Medicine 11, 89-103.

Cohen, S., Kamarck, T. \& Mermelstein, R. (1983). A Global Measure of Perceived Stress. Journal of Health and Social Behaviour, 24, 385-396.

Daniels, K., Guppy, A. (1992). Control, information-seeking preferences, occupational stressors and psychological well-being. Work and Stress October-December: 347-353.

Davis, W. L., \& Davis, D. E. (1972). Internal-external control and attribution of responsibility for success or failure. Journal of Personality 40, 123-136

DiMatteo, M. R., Shugars, D.A., \& Hays., R.D. (1993). Occupational stress, life stress and mental health among dentists. Journal of Occupational and Organizational Psychology June, 153-162.

Evans, B. J., Coman, G. (1993). General versus specific measures of occupational stress: An Australian police survey. Stress Medicine January, 11-20.

Halpin, G. Harris, K. \& Gerald. H. (1985), Teacher Stress as Related to Locus of Control, Sex and Age. Journal of Experimental Education, 53 (3), 136-140

Hans, T. (2000). A meta-analysis of the effects of adventure programming on locus of control. Journal of Contemporary Psychotherapy, 30(1), 33-60.

Hattie, J. A., Marsh, H. W., Neill, J. T. \& Richards, G. E. (1997). Adventure Education and Outward Bound: Out-of-class experiences that have a lasting effect. Review of Educational Research, 67, 43-87.

Howatt, W. A. (2011). Roles of internal locus of control and self-efficacy on managing job stressors and Ryff's six scales of psychological well-being. Walden Dissertations and Doctoral Studies. 1009. https://scholarworks.waldenu.edu/dissertations/1009

Ivancevich, J. M., \& M. T. Matteson, M.T. (1980). Stress and work: A managerial perspective Glenview, IL: Scott, Foresman. 
Jha, R. K., \& Bano, B. (2012). Impact of locus of control on job stress: An empirical study. International Journal of Decision Making in Supply Chain and Logistics, 3(1), 87-95.

Lefcourt, H. (1982).Locus of control: Current trends in theory and research. 2nd ed. Hillsdale, NJ: Lawrence Erlbaum.

Lindholm, M. (2006). Working conditions, psychosocial resources and work stress in nurses and physicians in chief managers' positions. Journal of nursing management, 14(4), 300-309.

Lowe, D. (2019). The Moderating Effects of Adaptive Coping Styles and Locus of Control on Stress Outcomes by Reported Level of Masculinity, Technology at Work, and Level of Perceived Stress. Electronic Theses and Dissertations, 252. https://scholarworks.sfasu.edu/etds/252

Mamlin, N., Harris, K. R. \& Case, L. P. (2001). A Methodological Analysis of Research on Locus of Control and Learning Disabilities: Rethinking a Common Assumption. Journal of Special Education, 34(4), 214-225.

Meng, X. H., He, Y. H., Yu, S. F., \& Qi, X. Y. (2008). Relationship between work locus of control and occupational stress in oil workers. Chinese journal of industrial hygiene and occupational diseases, 26(12), 718-720.

Murray, D. (1990). The performance effects of participative budgeting: An integration of intervening and moderating variables. Behavioral Research in Accounting, 2,104-123.

Nakasis, K., \& Ouzouni, C. (2008). Factors influencing stress and job satisfaction of nurses working in psychiatric units. Health science 2(4), 183-195

Phares, E. J., Wilson, K. G. \& Klyver, N. W. (1971). Internal-external control and the attribution of blame under neutral and distractive conditions. Journal of Personality and Social Psychology, 18, 285-288.

Roddenberry, A. \& Renk, K., (2010). Locus of Control and Self-Efficacy: Potential Mediators of Stress, Illness, and Utilization of Health Services in College Students, Journal of Child Psychiatry, 41 (4) 
Rotter, J. B. (1966). Generalized expectancies for internal versus external control of reinforcement. Psychological Monographs: General and Applied, 80(1), 1-28. https://doi.org/10.1037/h0092976

Sabraian, A., Omdiyar, B., Ghanizadeh, A., \& Bazrafshan, A. (2014). Association of Job Stress with Locus of Control in Nurses. Shiraz E Medical Journal, 15(2).pgs 132-144

Selye, H(1976). The Stress of Life. New York: McGraw Hill.

Sinha, V., Bhattacharya, S., \& Sharma, P. (2019). Locus of control and its impact on stress at work and job satisfaction. International Journal of Public Sector Performance Management, 5(3-4), 446-460.

Spector, P. E. (1988). Development of the work locus of control scale. Journal of Occupational Psychology, 61, 335-340.

Sünbül,A. M. (2003). An analysis of relations among locus of control, burnout and job satisfaction in Turkish high school teachers. Australian Journal of Education, 47(1), 58-72.

Torestad, B., Olah, A. \& Magnusson, D. (1989). Individual control, intensity of reactions and frequency of occurrence: An empirical study of cross-culturally invariant relationships. Perceptual and Motor Skills June, 1339-1350.

Yukl, G. A., \& Latham, G. P. (1978). Interrelationships among employee participation, individual differences, goal difficulty, goal acceptance, goal instrumentality, and performance. Personal Psychology Summer, 304-323. 